\title{
Crown cover of native trees in the structural development of reforestations in Rondônia ${ }^{1}$
}

\author{
Michelliny Pinheiro de Matos Bentes ${ }^{2 *}$, Rodrigo Barros Rocha ${ }^{3}$, Ana Luma Caldas Almeida
}

$10.1590 / 0034-737 X 201764050001$

\begin{abstract}
The objective of this study was to assess the initial development of a reforestation structure using the crown projection method as an indicator to monitor the recovery in degraded areas in the State of Rondônia. The method consisted of correlating canopy projection data with structural performance variables of six native tree species of the Amazon region. The study found that the species "large acacia" had the best capacity to promote shading, favor rapid covering, protection, and stabilization of the soil in the initial phase, at 24 months, with a crown area of $62.82 \mathrm{~m}^{2}$. The crown projection method was suitable to identify the native trees that stand out in the initial years of restoration of degraded areas. The method can be used to indicate variations in the structural development of species as a function of site quality and to assist in determining the feasibility of native tree species selected for reforestation. Therefore, further studies on this approach are needed to develop models of crown cover prediction and validate crown cover as an indicator of reforestation development in restoration processes in the Amazon region.
\end{abstract}

Key words: reforestation; environmental suitability; Brazilian Forest Code.

\section{RESUMO}

\section{Cobertura de copa de espécies arbóreas nativas no desenvolvimento estrutural de reflorestamentos em Rondônia}

O objetivo deste trabalho foi avaliar o desenvolvimento inicial da estrutura de um reflorestamento mediante o método de projeção de copas, como indicador de monitoramento de processos de recomposição em áreas alteradas no Estado de Rondônia. O método consistiu na correlação de dados da projeção de copa com variáveis de desempenho estrutural de seis espécies arbóreas nativas da região amazônica. Constatou-se que a espécie acácia grande foi a que se destacou com a melhor capacidade de promover sombreamento, favorecer a rápida cobertura, proteção e estabilização do solo em fase inicial, aos 24 meses, com área de copa de 62,82 $\mathrm{m}^{2}$. O método de projeção de copas mostrou-se adequado para informar as espécies arbóreas nativas que se destacam nos anos iniciais da recomposição de uma área alterada. Pode servir para indicar as variações do desenvolvimento estrutural das espécies em função da qualidade de sítio, e auxiliar na averiguação da viabilidade das espécies arbóreas nativas escolhidas para o reflorestamento. É necessário, portanto, ampliar estudos com esse enfoque, a fim de se desenvolver tais modelos de predição de cobertura de copas, e validar a cobertura de copas como indicador da evolução de reflorestamentos em processos de recomposição na Amazônia.

Palavras-chave: reflorestamento; adequação ambiental; Código Florestal Brasileiro.

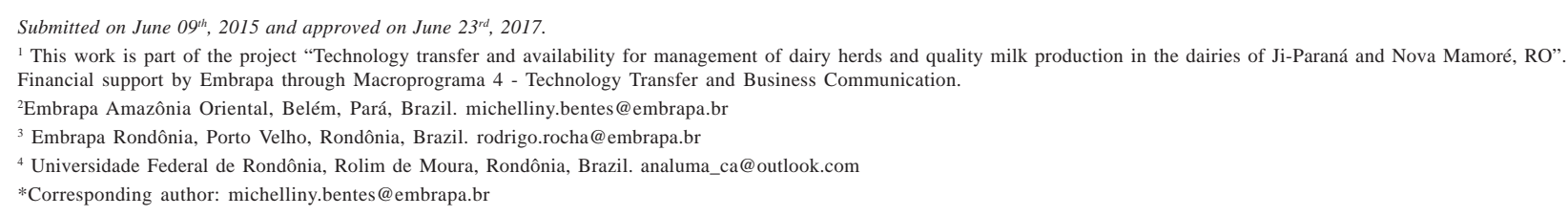




\section{INTRODUCTION}

The recomposition, recovery, or restoration of degraded areas in the Brazilian Amazon depends on the integration of technical knowledge and commitment towards reconciling environmental conservation and job and income generation in the local productive chains.

In general, the technical guidance on forest restoration focuses on the selection of species, production models that have market value, and planting material available for local use. However, there is little information on efficient monitoring routines (Melo et al., 2007, 2010; Andrade et al., 2012; Pacto, 2013) to assess the evolution and effectiveness of functional recovery of the new forest formation (Pacto, 2013), or even recommendations for future reforestation management.

In this context, indicators can serve to evaluate attributes of areas in restoration and the intensities of this alteration. The usefulness of the indicators in these processes, whether for commercial or conservation purposes, falls on a series of practical factors. One of them is the evaluation of development performance of the forest component, or native vegetation, as to its structure and function, to produce food, energy, and environmental services. The use of these indicators is directly related to the sources of anthropic activities that cause changes in the environment (Dajoz, 1973) and/or will depend on the objectives of the planting (Melo et al., 2007).

The functioning parameters of natural communities and the status that the implanted community was supposed to reach in the proposed time were the main factors to be considered in the recommendations for the establishment of forest restoration projects in the recent past (Rodrigues \& Gandolfi, 1996). Currently, besides this concern, it is also important to promote the restoration of ecological processes responsible for the reconstruction of a forest in commercial plantations, to incorporate the farm into the new legal framework, maintain sustainability, and ensure productivity (Guerin \& Isernhagen, 2013; Pacto, 2013).

Thus, monitoring the structural development of reforestation is an essential step to assess the degree of success of the restoration process (Pacto, 2013), generating important data from the initial stage of establishment, which can serve to assess the ecological trajectory of the species in more consistent evaluations of production in the future.

Crown cover or projection can be a consistent indicator to inform the level of structural development of forests in restoration, considering the importance of forest canopy formation. The forest canopy controls the amount of light, protects the soil from leaching impacts, influences moisture level, temperature, and the microclimate, among other processes (Melo et al., 2007, 2010). Thus, the soil cover by tree crown is an important indicator to infer whether the selected species ensures effective structural formation of the canopy (Pacto, 2013).

In Areas of Permanent Preservation (APP), the use of native species for restoration is mandatory and must occur in such a way that the new forest structure approaches the previous one (Faria et al., 1997; Brazil, 2012). In Legal Reserve Areas (ARL), the guidelines for commercial reforestation must be complied with while observing the scope of variations in the state environmental legislation.

The objective of this work was to evaluate the initial structural development of a reforestation using the crown projection method as an indicator of the recovery process in degraded areas in the State of Rondônia.

\section{MATERIAL AND METHODS}

The study area is located in the experimental field of the Brazilian Agricultural Research Corporation (Emprapa), in the municipality of Presidente Médici, Rondônia ( $11^{\circ} 17$ 'S and $61^{\circ} 55^{\prime}$ 'W, $390 \mathrm{~m}$ altitude). The experimental field access is located $10 \mathrm{~km}$ along BR-364 Road, from Presidente Médici to Cacoal, in the physiographic microregion of Ji-Paraná. The farm has total area of 95.63 ha and since the 1980 has been used for experimentation in animal production (Pereira, 2008; Townsend et al., 2000).

The predominant climate of the region is type Aw characterized as humid tropical, rainy in the summer and dry in the winter, according to the Köppen classification. Rainfall varies between 2,000 and 2,300 $\mathrm{mm}$ per year, the annual average temperature reaches $24.5^{\circ} \mathrm{C}$, the average relative humidity is $80 \%$, with heavy rainfall from November to April, when $80.3 \%$ of the total annual rainfall concentrates (Scerne et al., 2000). The predominant soils in the region are Argisols (Embrapa, 2006). The physical and chemical attributes at the time of the implementation of the restoration plan are detailed in Pereira (2008). The relief is slightly undulating, with original vegetation classified as Open Ombrophylous Forest with Palms, according to IBGE (2012).

The Embratel River runs inside the farm. It is the main watercourse and source of local water supply, as well as object of remediation of its environmental conditions in this study. With an area of about $500 \mathrm{~m}$ in the experimental field, the river reaches a total length of $12 \mathrm{~km}$ from its source on the hill adjacent to the farm until reaching the Machado river (Capelasso, 2010; Pereira, 2008), the main hydrographic element of the Machado or Ji-Paraná Basin.

The adjacent and surrounding areas of the river were occupied by brachiaria grass (Brachiaria sp.) in animal grazing system for at least 15 years, thus requiring the restoration of native vegetation, according to the guidelines of the current environmental legislation. 
The reforestation of the area took place in January 2008, according to the design, arrangements, and species described in Bentes-Gama et al. (2013), in three plots of different areas: A1 - $3589 \mathrm{~m}^{2}$ (0.36 ha); A2 - $2060 \mathrm{~m}^{2}(0.20$ ha); and A3 - $908 \mathrm{~m}^{2}$ (0.09 ha), at spacings 10mx10m, 5mx5m, and $3 \mathrm{mx} 3 \mathrm{~m}$, respectively. In the arrangements, $50 \%$ were initial secondary species, $33 \%$ pioneer species, and $17 \%$ climax species. All species occur naturally in the Western Amazon and were planted sequentially in rows: Açaí (Euterpe precatoria Mart.) - Arecaceae; Ipê amarelo (Handroanthus albus (Chamiso) Mattos) - Bignoniaceae; Jatobá (Hymenaea courbaril var. stilbocarpa) - Caesalpinaceae; Sóbrasil (Colubrina glandulosa Perkins) Rhamnaceae; Bandarra (Schizolobium amazonicum Vell) - Caesalpinaceae, with autoecology described in Carvalho (1994 and 2006); and two legume species popularly known in the region as "large acacia" and "small acacia", which have not been identified at species level. The species were selected by availability in the nursery, kindly provided by the Environmental Police Battalion of the municipality of Candeias do Jamari, Rondônia.
Structural variables of reforestation were selected according to field methodologies described in Bentes-Gama et al. (2013), Capelasso (2010), and Pereira (2008). Evaluations were carried out at 24 months after planting, measuring the total height $(\mathrm{m})$, root collar diameter $(\mathrm{cm})$, and crown radii in the longitudinal and transverse directions (m) of living individuals (Figure 1).

The crown projections were obtained according to the method tested by Melo et al. (2007), considering an ellipse area: $A_{\text {crown }}=\pi \cdot R C_{1} \cdot R C_{2}$, where: $\mathrm{A}_{\text {crown }}$ is the crown area $\left(\mathrm{m}^{2}\right) ; \pi: 3.14159 ; \mathrm{RC}_{1}$ is the crown radius in the longitudinal direction $(\mathrm{m}) ; \mathrm{RC}_{2}$ is the crown radius in the transverse direction $(\mathrm{m})$, to develop a response surface model for predicting the response of the dependent variable crown area $\left(\mathrm{A}_{\text {crown }}\right)$ as a function of the independent variables (height, root collar diameter, and crown radius). Data were analyzed with the program Sisvar 5.3 Build 77 and the analysis of statistical selection criteria with the multiple regression adjustment $(\mathrm{y}=\mathrm{b} 0+\mathrm{b} 1 * \mathrm{~h}+\mathrm{b} 2 * \mathrm{dc}+$ b3*Rcrown $1+$ b4*Rcrown2) for unbalanced experiments (Ferreira, 2011).

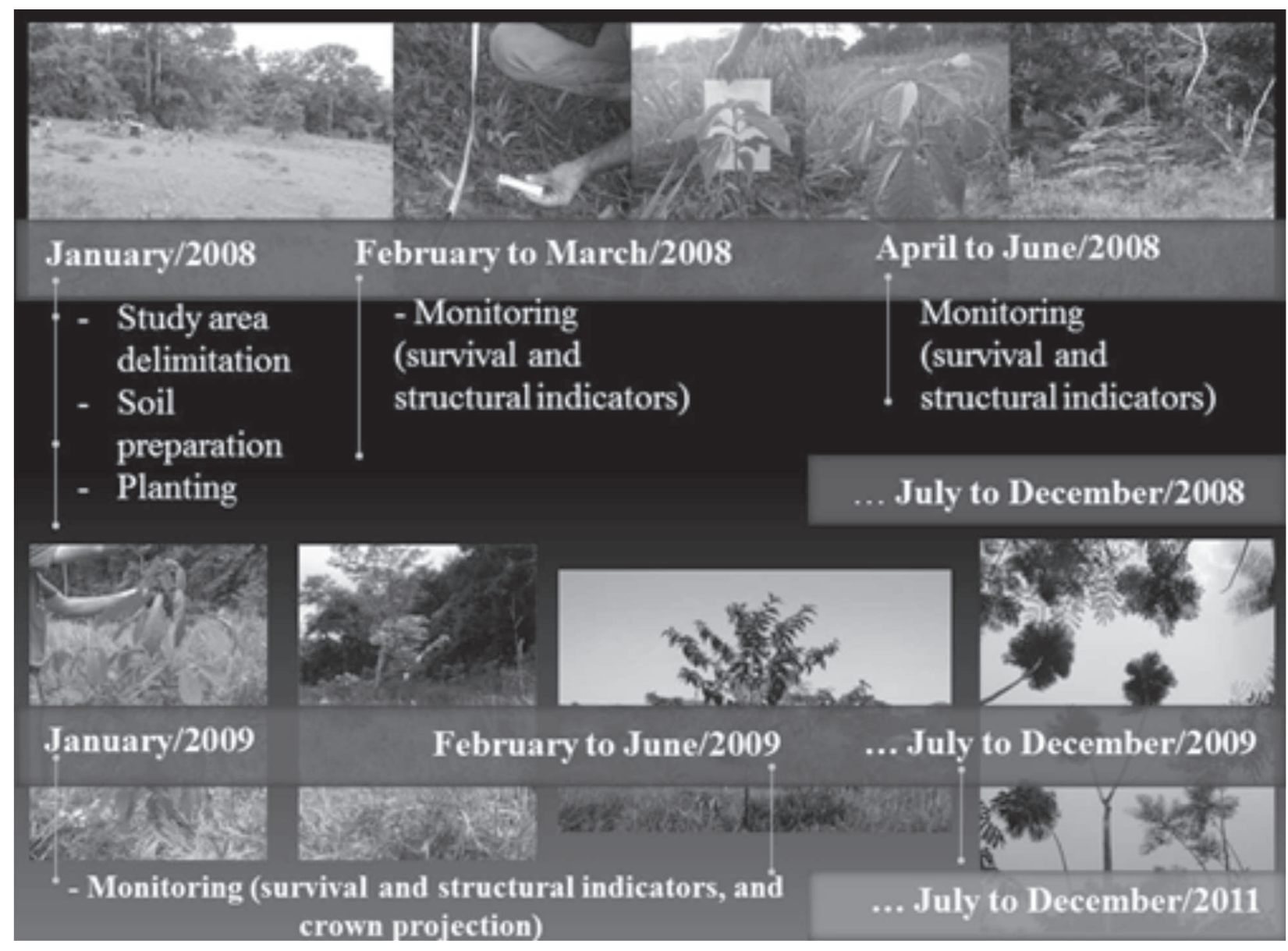

Figure 1: Timeline of the development of the structure of restoration using native tree species in Presidente Médici, Rondônia. Adapted from Bentes-Gama et al (2013), Capelasso (2010) and Pereira (2008). Where: January/2008: stage of study area delimitation, soil preparation, and planting; February/2008 to June/2008: stage of monitoring and evaluation of species survival; July/2008 to December/2008: stage of monitoring and replanting; January/2009 to December/2011: Continuation of monitoring and collection of structural data on planting and control of weed competition. 


\section{RESULTS AND DISCUSSION}

The variables monitored indicated that there is an increase in reforestation structure with increasing age (Figure 1 and Figure 2), as expected from restoration processes that are based on the use of native species (BentesGama et al., 2013; Capelasso, 2010; Pereira, 2008; Rodrigues \& Gandolfi, 1996).

The growing performance of the selected native forest species showed good adaptability and good initial development compared with the results of restoration processes implemented in similar conditions of soil and spacing in the legal Amazon (Bentes-Gama et al., 2013; Capelasso, 2010; Tonini \& Arco-Verde, 2005).

The models generated for the prediction of crown cover according to age are presented in Figure 2. The species large acacia, one of the unidentified leguminous tree, but frequently used in the riparian forest recovery campaigns in the municipality of Porto Velho and surroundings, showed the best performance for the crown cover indicator compared with those obtained for the other species tested, with the multiple regression model giving a coefficient of determination of $\mathrm{R}^{2}=0.98$ and the lowest residual dispersion (Figure 2).

At 24 months after planting, the species proved to be capable of promoting rapid ground cover, with an actual crown area of $62.82 \mathrm{~m}^{2}$, on average, per individual. The shading provided by this species can favor reduction in implantation costs, directly and positively affecting reduction in weed competition, very common in the initial phase of plantations (Melo et al., 2007). This is one of the main criticisms on the part of farmers, and a potential factor
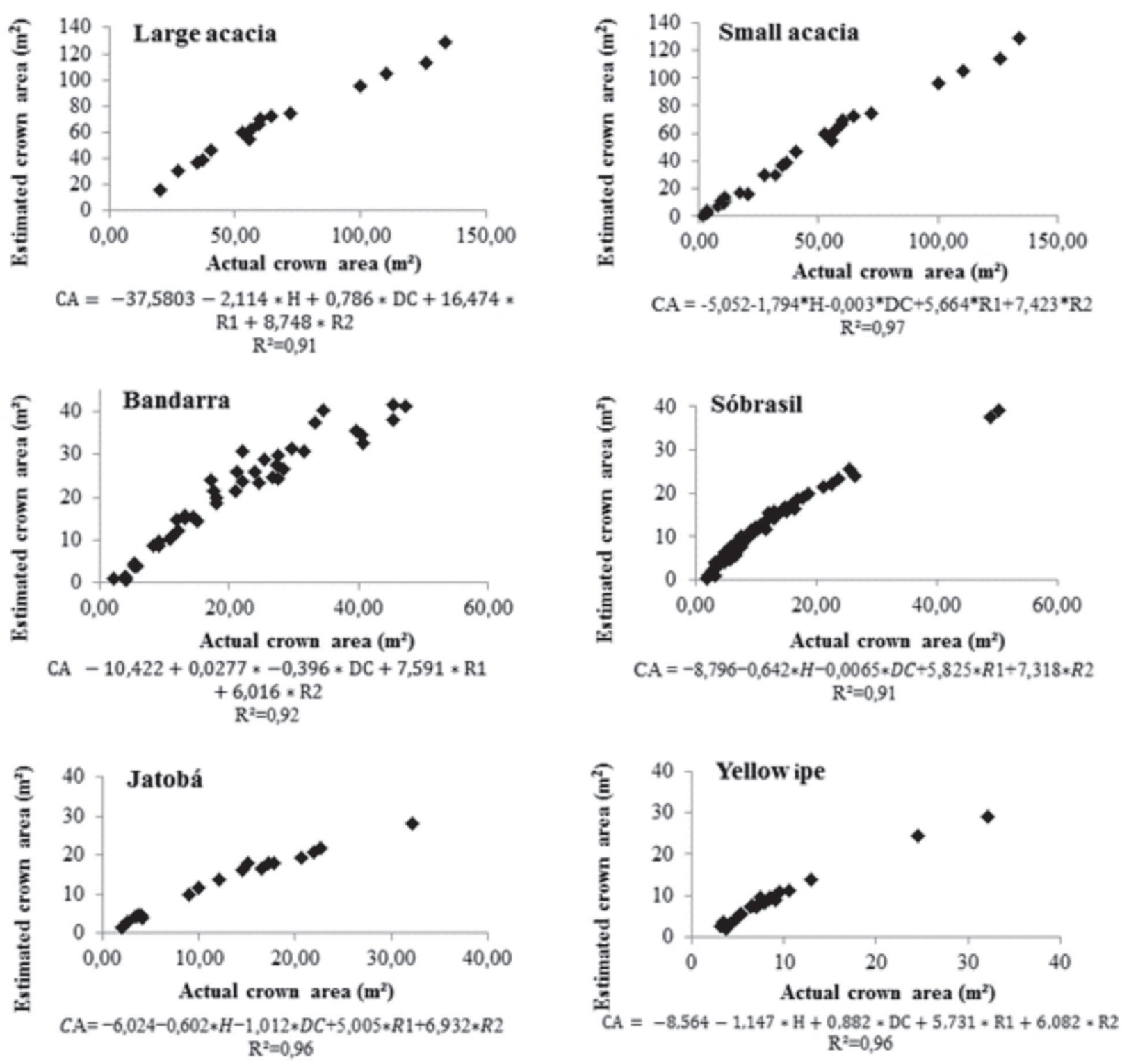

Figure 2: Response surface of the biological model to estimate the crown area (CA) of native tree species with ages varying from 1 to 24 months in forest restoration, Presidente Médici, Rondônia.

Rev. Ceres, Viçosa, v. 64, n.5, p. 451-456, set/out, 2017 
limiting the adoption of reforestation for restoring degraded areas in the Amazon region (Figure 3).

Both species, bandarra and jatobá, formed an actual crown area of $20.79 \mathrm{~m}^{2}$ and $12.77 \mathrm{~m}^{2}$, respectively, at 24 months after planting; while the smallest areas were found for the species sóbrasil, small acacia, and yellow ipe, with $11.28 \mathrm{~m}^{2}, 9.47 \mathrm{~m}^{2}$, and $8.52 \mathrm{~m}^{2}$ of crown area, respectively (Table 1). These results are compatible with those found by Tonini and Arco-Verde (2005), in older plantings, at 84 months of age, in the State of Roraima, where the crown area of the species purple ipe (Tabebuia avellaneadae) and jatobá (Hymenaea courbaril) reached, on average, $10.40 \mathrm{~m}^{2}$ and $6.60 \mathrm{~m}^{2}$, respectively.

Although the crown projection area has varied between species, the method used in this study can serve to indicate variations in the structural development of the species depending on site quality and local environmental variations and assist in verifying the suitability of native species selected for forest restoration.

This study has shown, as in Melo et al. (2007), that the models tested demonstrated the feasibility of the relation of crown cover with reforestation age. These findings highlight the need for further studies of this nature to validate crown cover as an indicator of development in restoration processes in the Amazon region with different reforestation ages.

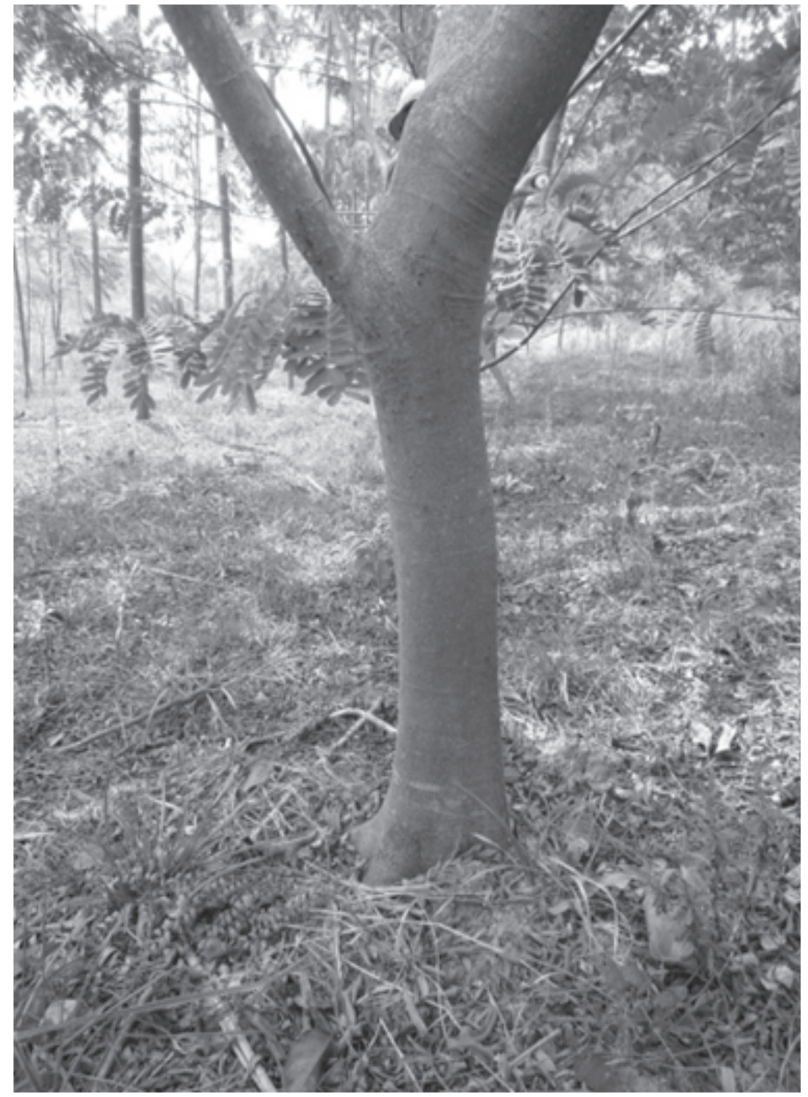

Figure 3: Trunk Profile of "large acacia" (NI1) at 24 months of age in restoration of degraded area, Presidente Médici, Rondônia.

Table 1: Area, cover, and projection of the crown of native tree species, and area of plots in forest restoration, Presidente Médici, Rondônia

\begin{tabular}{lcccc}
\hline Species & $\begin{array}{c}\text { Average crown } \\
\text { area }\left(\mathbf{m}^{\mathbf{2}}\right.\end{array}$ & $\begin{array}{c}\text { Average crown } \\
\text { cover }(\boldsymbol{\%})\end{array}$ & $\begin{array}{c}\text { Average crown } \\
\text { projection }(\boldsymbol{\%})\end{array}$ & $\begin{array}{c}\text { Plot area } \\
\left(\mathbf{m}^{2}\right)\end{array}$ \\
\hline Large acacia & 62.82 & 36.90 & 2.31 & 2850 \\
Bandarra & 20.79 & 32.10 & 0.73 & 2850 \\
Jatobá & 12.77 & 2.80 & 0.15 & 8500 \\
Sóbrasil & 11.28 & 9.60 & 0.14 & 8500 \\
Small acacia & 9.47 & 4.30 & 0.33 & 2850 \\
Yellow ipe & 8.52 & 2.50 & 0.10 & 8500 \\
\hline
\end{tabular}

\section{CONCLUSION}

The method used to estimate crown cover was suitable to indicate which species had the best structural characteristics in the initial years of the restoration of a reforested area in Rondônia. The species "large acacia", with crown area of $62.82 \mathrm{~m}^{2}$ at 24 months, had the best performance among the native species.

Models for the prediction of crown cover as a function of age can be developed to indicate the variations in the structural development of native trees depending on the quality of both the site and environment and assist in the investigation of the feasibility of using these species in reforestation. Therefore, further studies on this approach are needed to develop models of crown cover prediction and validate crown cover as an indicator of reforestation development in restoration processes in the Amazon region.

\section{ACKNOWLEDGEMENTS}

The authors thank the forest engineers Neilton Santos Pereira, Giovana Fiorella Zamora López, and Poliana Heloisa da Silva Capelasso for their valuable contributions in the different stages of the project, PIBIC Embrapa-CNPq for the scientific initiation grants provided from 2008 to 2011; researchers and analysts of the Animal Production Center and Forestry Production Center, and the experimental field assistants at Embrapa Presidente Médici, Rondônia. 


\section{REFERENCES}

Andrade CM, Salman AKD \& Oliveira TK de (2012) Guia Arbopasto: manual de identificação e seleção de espécies arbóreas para sistemas silvipastoris. Brasília, Embrapa. 342p.

Bentes-Gama MM, Rocha RB, Salman AKD, Mendes AM \& Figueiró MR (2013) Reforestation feasibility in area formerly used for cattle rasing in the State of Rondônia, Northwest Brazilian Amazon. Revista Árvore, 37:1001-1010.

Brasil (2012) Lei ${ }^{\circ}$ 12.651, de 25 de maio de 2012. Dispõe sobre a proteção da vegetação nativa; altera as Leis nos 6.938, de 31 de Agosto de 1981, 9.393, de 19 de dezembro de 1996, 3 11.428, de 22 de dezembro de 2006; revoga as Leis nos 4.771, de 15 de setembro de 1965 , e 7.754, de 14 de abril de 1989, e a Medida Provisória n 2.166-67, de 24 de Agosto de 2001; e dá outras providências. DOU,28/05/2012, Seção 1, p. 1-8.

Capelasso PHS (2010) Comportamento de espécies arbóreas nativas na recuperação de área alterada no município de Presidente Médici - Rondônia. Monografia. Instituto João Neórico, Porto Velho. 79p.

Carvalho PER (2003) Espécies arbóreas brasileiras. Brasília, Embrapa Informação Tecnológica / Colombo, Embrapa Florestas. $1039 \mathrm{p}$

Carvalho PER (2006) Espécies arbóreas brasileiras. Brasília, Embrapa Informação Tecnológica / Colombo, Embrapa Florestas. $647 \mathrm{p}$

Dajoz R (1973) Ecologia Geral. São Paulo, Vozes. 472p.

Embrapa - Empresa Brasileira de Pesquisa Agropecuária (2006) Sistema brasileiro de classificação dos solos. $2^{\mathrm{a}}$ ed. Rio de Janeiro, CNPS. 212p.

Faria JMR, Davide AC \& Botelho AS (1997) Comportamento de espécies florestais em áreas degradadas, com duas adubações de plantio. Cerne, 3:25-44.

Ferreira DF (2011) Sisvar: a computer statistical analysis system. Ciência e Agrotecnologia, 35:1039-1042.

Guerin N \& Isernhagem I (2013) Plantar, criar e conservar: unindo produtividade e meio ambiente. São Paulo, Instituto Socioambiental. $143 \mathrm{p}$

IBGE - Instituto Brasileiro de Geografia e Estatística (2012) Manuais técnicos em geociências. $2^{a}$ ed. Rio de Janeiro, IBGE. 271p. (Manual Técnico da Vegetação Brasileira, 1).

Melo ACG, Reis CM \& Resende RU (2010) Guia para monitoramento de reflorestamentos para restauração. São Paulo, Secretaria do Meio Ambiente. 10p. (Circular Técnica, 1).

Melo ACG, Miranda DLC \& Durigan G (2007) Cobertura de copas como indicador de desenvolvimento estrutural de reflorestamentos de restauração de matas ciliares no Médio Vale do Paranapanema, SP, Brasil. Revista Árvore, 31:321-328.

Pacto - Pacto pela recuperação da Mata Atlântica (2013) Protocolo de monitoramento para programas e projetos de restauração florestal. Disponível em: <http://www.pactomataatlantica.org.br/protocolo-projetos-restauracao. aspxlang=pt-br $>$. Acessado em: 20 de julho de 2014.

Pereira NS (2008) Recuperação de área alterada em sistema de criação de búfalos em Presidente Médici, Estado de Rondônia Monografia. Faculdade de Ciências Humanas, Exatas e Letras de Rondônia, 47p.

Rodrigues RR \& Gandolfi S (1996) Recomposição de florestas nativas: princípios gerais e subsídios para uma definição metodológica. Revista Brasileira de Horticultura, 2:04-15.

Scerne RMC, Santos AOS, Santos MM \& Antônio Neto F (2000) Aspectos agroclimáticos do município de Ouro Preto D'Oeste RO: atualização quinquenal. Belém, Superintendência Regional da Amazônia Oriental. 48p.
Tonini H \& Arco-Verde MF (2005) Morfologia da copa para avaliar o espaço vital de quatro espécies nativas da Amazônia. Pesquisa Agropecuária Brasileira, 40:633-638.

Townsend CR, Magalhães JA, Costa NL, Pereira RGA \& Silva Neto FG (2000) Condições térmicas ambientais sob diferentes sistemas silvipastoris em Presidente Médici - Rondônia. Porto Velho, Embrapa / CPAF Rondônia, 4p. (Comunicado Técnico, $188)$.

Rev. Ceres, Viçosa, v. 64, n.5, p. 451-456, set/out, 2017 